\title{
Measuring Decentralisation in Reforms Era: A Case of Kalyan-Dombivli, India
}

\author{
Vidya Sagar Pancholi \\ Research Scholar, Department of Regional Planning, School of Planning and Architecture, New Delhi, India \\ Email: arsagar@gmail.com
}

Received 2 April 2014; revised 23 May 2014; accepted 7 June 2014

Copyright @ 2014 by author and Scientific Research Publishing Inc. This work is licensed under the Creative Commons Attribution International License (CC BY). http://creativecommons.org/licenses/by/4.0/

cc) (†) Open Access

\begin{abstract}
Since last couple of decades, there is an emerging trend of decentralisation and India is no exception to such a trend. Studies that measure decentralisation in India, however, are mostly comparative and target a limited set of parameters. This paper, attempts at a comprehensive examination of a case of Kalyan-Dombivli (KD), a fringe sub-city to Mumbai. The analysis brings out that over the past seven years (since the beginning of the centrally sponsored urban renewal program), even though the local body in KD had higher resources for local development, its functional authority, fiscal autonomy, and accountability has been significantly re-centralised towards higher level governments. The case analysis brings out key lessons in terms of need for focusing on the empowerment (functional and fiscal) of local bodies and creating accountability structures that are effective and responsive to the local citizenry.
\end{abstract}

\section{Keywords}

Decentralisation, JNNURM Program, Kalyan-Dombivli (KD)

\section{Introduction}

Since the late 1980s, decentralisation has become an increasingly widespread and significant dimension of political and administrative reform. Although, the basic objective of decentralisation is to empower the municipal bodies both administratively as well as financially (Bagchi, 2003) in order for them to render local services that are responsive to the local needs (Woolman \& Goldsmith, 1990). However, a wide variation in the institutional contexts in which decentralisation reforms emerged across various countries has resulted in a diverse set of objectives across individual decentralisation schemes. Measuring the progress made towards achieving these diverse objectives, therefore, requires a detailed analysis of each individual case.

In the case of India, the 74th amendment to the constitution (the Act) sought to decentralise decision making 
in cities and towns through the creation of elected urban local bodies (ULBs). Although such ULBs existed even prior to the passing of the Act, however, they not only had very little role to play, their performance also deteriorated over the years (IDF, n.d.). Key features of the Act were: introduction of a list of functions for the ULBs, establishment of ward/s committees in areas having a population of over 0.3 million, periodic and timely elections of ULBs, devolution of finances to the ULBs as per suggestions of the State Finance Commissions (SFCs), and coordination of multiple agency functions through the Metropolitan Planning Committee (MPCs) and District Planning Committee (DPCs) (Batra, 2009).

Such elaborate provisions, nonetheless, could not successfully embrace the notion of "local self-governance" as State governments have not satisfactorily devolved functions and finances to the ULBs (Rao \& Bird, 2010). Considering the challenges posed by an emerging trend in urbanisation, and an increasing pressure for better service delivery, Central government of India came out with an urban renewal program in the name of Jawahar Lal Nehru Urban Renewal Mission (JNNURM) in the year 2005. The program works on a carrot and stick approach of massive central government funding hinged on the implementation of a package of neoliberal reforms aimed primarily at rendering cities more market-friendly (Coelho et al., 2011: p. 11). The JNNURM program has however been highly criticised for keeping a myopic vision on the actual urban problems (see for instance; Mukhopadhyay, 2006; Banerjee-Guha, 2009). A limited devolution by the state governments and limitations with the JNNURM program has resulted in an uneven progress on the empowerment of the ULBs in India.

On the other hand, studies that measure decentralisation in India are mostly comparative and target a limited set of parameters (see for instance Chattopadhyay, 2004; Bagchi, 2003) leaving a scope for more exhaustive studies, or rather case studies that assess comprehensively, the extent and degree of decentralisation at that particular chosen case. Such an examination is indeed necessary, as, for development to be inclusive and truly sustainable, it is very important that local bodies take their own decisions, and a comprehensive measure of such capabilities can enhance the knowledge of policy makers which can result in a better targeting of development programs.

Gaining motivation from such an opportunity, this paper looks at examining a case of Kalyan-Dombivli (KD) - a city with a population of 1.24 million (Census, 2011) along the fringe of Mumbai and discusses future directions in the light of the research findings. The case of KD assumes significance with the findings of Denis, Mukhopadhyay, \& Zérah (2012) as they highlight that during the last decade in India urbanisation was more dispersed with a high population growth in small and medium towns and towns along the periphery of big metro cities. Studying the case of KD, therefore, can reveal interesting findings from the perspective of inclusive and sustainable development. The paper is structured under three broad sections: the first section presents insights on measuring extent and degree of decentralisation; the second section studies the case of KD; while the third section discusses the main findings.

\section{Decentralisation and Its Measurement: A Brief Survey}

Decentralisation is commonly defined as the process of transferring decision making powers to the sub-national governments. It is a multifaceted process where at least three different dimensions jointly characterise its functioning: the scope of authority, the degree of autonomy, and the direction of accountability (Martinez-Vazquez \& Timofeev, 2010). Policy literature brings out three dominant forms of decentralisation: de-concentration, delegation and devolution (Bird \& Wallich, 1993). Through de-concentration, central government transfers some authority to the sub-national branches that are appointed by and accountable to the centre/higher hierarchy. Under delegation, locally elected government bodies assume new responsibilities subject to strict regulations by the upper level government. The process of devolution represents full transfer of responsibility, decision-making, resources and revenue generation to an independent locally elected public authority. Thus, while de-concentration increases local governments' power only related to the delivery of services, delegation allows local governments to (some extent) also finance such services while reserving the powers regarding regulation with the higher level governments. It is only devolution through which local governments receive powers of regulation, finance and service delivery with respect to services that fall within their exclusive spheres of responsibility.

This multidimensionality of decentralisation, therefore, poses challenges in measuring the extent and the degree of decentralisation. For instance, while measuring fiscal aspects of decentralisation, several studies analyse either revenue or expenditure from sub-national governments (Duc, 2008; Halder, 2007). However, these studies fail to consider the role of fiscal autonomy of the sub-national governments which can only be assessed by 
knowing the types of grants and localness of taxes along with revenue and expenditure measures. Therefore, fiscal decentralisation measures should capture both; administrative measures (share of own source income in total income "or" share of grants in total income, share of untied grants in total grants) and fiscal measures (share of own source revenue of the ULB in total own revenue of local, state and central government) of decentralisation (Chattopadhyay, 2004).

Likewise, measuring scope of authority and direction of accountability of the local body in decentralisation requires an in-depth study of local body's functioning. To understand the way a local body functions in decentralisation, it is essential to interpret laws and regulations that decide the mandate of the local body. It is further essential to assess the role played by other institutions that also operate locally and the extent such institutions collaborate/conflict with local body's mandate. Such institutions may affect local body's scope of authority and also direction of accountability in local service delivery. Similarly, it is important to investigate the role of central and state government development schemes/programs in affecting local body's authority in preparing local development agenda and local level planning. Such schemes/program may curtail local government's authority and can shift accountability from downwards to upwards. Lastly, there is also a need of understanding the type and effectiveness of accountability mechanisms at the local level. Such an exercise would entail assessing the effectiveness of "points of interfaces" between local government and higher level governments and between local government and local citizens. This would also require understanding the role of civil society organisations in the process of governance.

\section{The Case Analysis}

\subsection{An Overview of Kalyan-Dombivli}

Kalyan-Dombivli (KD) is located approx. 60 kms north-east of Mumbai, India (refer to Figure 1). It has a population of 1,246,000 and comprises an area of $67.65 \mathrm{sq} \mathrm{km}$. (Census, 2011). KD city is also called as the biggest middle class township in the whole of the Mumbai Metropolitan Region (MMR) and popularly described as a dormitory town of Mumbai. The City is an important hub of residential, educational and social activities in the region. It has a literacy rate of 96.11 percent for males and 89.73 percent for females (Census, 2011). According to the first City Development Plan prepared by the Municipal Corporation of Kalyan-Dombivli in 2007, about 32.44 percent of the total population is engaged in non-agricultural activities, 0.78 percent of the population is working in household industries and 0.6 percent in agricultural activities. Overall, one-third of the city's population is working class population working in railways, banks, schools, colleges, companies etc. and most of these, other than trading community and self employed people, travel to Thane. Mumbai and other places big centres.
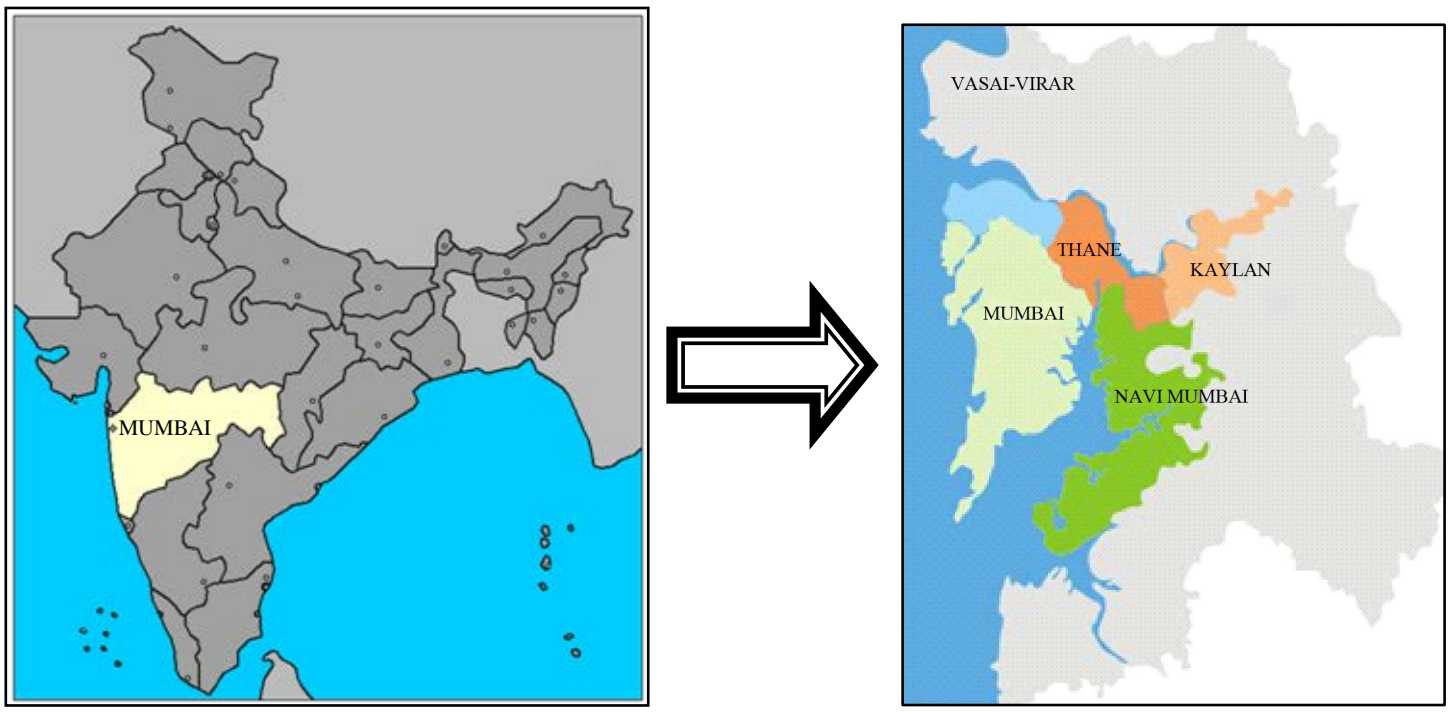

Figure 1. Location of Mumbai within Maharashtra, India, and Kalyan-Dombivli in the Mumbai Metropolitan Region; source: Google maps, 2014; MMRDA website, 2014. 
Being a part of the MMR, which is one of the fastest growing regions in India (Pethe et al., 2011), and also due to limitations with the physical expansion of Mumbai towards the west and south, KD has witnessed tremendous growth in population during the decades of 1981-2001 (CDP, 2012), along with other eastern parts of the region including Navi Mumbai, Thane, Vasai, Mira Bhayander. The growth of KD can also be attributed to its transport connectivity. Kalyan-Dombivli provides the preferred route to connect the northern part of India to southern regions. Finally, KD is also a centre of many industrial activities. While Kalyan is an important centre for trade and commerce in the region, industries are mainly located near Dombivli city. Kalyan city boasts trading of wholesale vegetable, milk products and agricultural products as well as trading of gold \& jewellery. Dombivli has an industrial area that comprises many small scale and large scale industries such as chemical, engineering, textile and others (Baid, 2008).

\subsection{Local Government in KD and Its Scope of Authority}

Kalyan-Dombivli is currently served by the Kalyan-Dombivli Municipal Corporation (KDMC) which came into being in 1983. The Municipal Corporation area has gone several changes since its formation and it now includes the cities of Kalyan, Dombivli, and 25 surrounding villages. KDMC is governed by the Bombay Provincial Municipal Corporation (BPMC) Act of 1949. The functioning of the KDMC rests upon a general body comprising 107 elected councillors, a standing committee of sixteen members, seven wards committees (since the introduction of the 74th Constitutional Amendment Act), a transport committee (since 1997), and the Municipal Commissioner who is the executive head of the Corporation.

The BPMC Act mentions 27 obligatory duties for the KDMC which include planning for social and economic development, maintenance of vital statistics, grant of licenses to professions and callings, provision of basic infrastructure like water supply, drainage, sewerage, roads and services such as solid waste management, fire fighting, street lights, education and primary healthcare. Besides this, the KDMC also provides several discretionary services that include provision of local transport service, construction and maintenance of swimming pool, auditorium, and a stadium.

Management and delivery of these services becomes more efficient, transparent and user friendly with the help of an "e-governance" platform, that was initiated in the year 2002 (Bhatnagar, 2007; Nishandar, 2011). The platform boasts three types of interfaces between citizens and the corporation, which are; citizen facilitation centres (which are currently 6 in numbers), a web-portal, and a $24 \times 7$ telephone help-line. While citizen facilitation centres help citizens with various payments; submission of tenders; and complaints related to services, the web-portal facilitates citizens with information on corporation's functioning; information required under the Right-to-Information Act; citizen charter; service forms; details required for availing any service; lodging of complaints; application for birth/death certificate; status of queries; and payment of water/property tax bills.

A survey of other institutions vested with the delivery of local services within KD, however, reveals that there are currently two specialised (para-statal) agencies that directly work in KD. These bodies actively participate and interfere in the functioning of the KDMC and strengthen the role of higher level governments in local governance.

One of these agencies is the Mumbai Metropolitan Region Development Authority (MMRDA) which was set up under the Mumbai Metropolitan Region Development Authority Act, 1974 to prepare plans, formulate policies and programs, implement projects and help in directing investments in the Mumbai Metropolitan Region (MMRDA Website, 2013). Functioning under the state government of Maharashtra, MMRDA influences KDMC's work through its regional planning guidelines, and implementation of various programmes related to the socio-economic development of the MMR. While in the case of planning, an absence of representation from the KDMC within the decision making body of the MMRDA and non-operationalizaton of Metropolitan Planning Committee (where representation of KDMC has been ensured) allows a complete control of the state government. In the case of program implementation, amongst other programs, MMRDA also performs the role of a state level nodal agency for the Urban Infrastructure and Governance (UIG) component of the JNNURM. This allows MMRDA in appraising projects submitted by the urban local bodies for availing JNNURM funding and in monitoring their physical and financial progress while strengthening its role as a non-democratic, techno-managerial body representing the state government.

The other agency, that has an influence over the functioning of the KDMC, is the Maharashtra Housing and Area Development Authority (MHADA) which deals with the construction of affordable housing within the en- 
tire state. MHADA is currently also handling the Basic Services for the Urban Poor (BSUP) component of the JNNURM program in Maharashtra. Such a responsibility entails channelising Central and state government funding to the local governments for the integrated development of slums while appraising the projects prepared by the urban local bodies. In the case of KD, there are currently 10 such slum redevelopment sites out of which 4 are taken as in-situ redevelopment projects and rest are planned as resettlement sites. The redevelopment of in-situ sites, in particular, has severely affected the temporarily displaced families due to delay in construction activities from the proposed duration of 18 months (came out during slum household surveys conducted in the year 2013). Such a delay happened mainly due to changes through time between the submission of detailed project report to the MHADA by the KDMC and the on-ground situation (came out during discussions with the MHADA officials). The mediation of MHADA as a state level nodal agency, between local bodies and higher level bodies, has therefore not turned out to be very fruitful from the perspectives of the urban poor.

It therefore can be said that there are although legal provisions and innovative platforms that strengthen KDMC's character as a local self-government, there are however para-statal bodies of the state that affect KDMC's functioning. These technical bodies extend the control of the state government in the process of local and regional development. Presence of these agencies raises serious concerns regarding empowerment of the KDMC and perhaps other local bodies as well that fall within the Mumbai Metropolitan Region.

\subsection{Degree of Autonomy of the KDMC}

With regards to the fiscal powers of the KDMC, the BPMC Act brings out potential sources of revenue that include; user charges and surcharges on civic services, proceeds of the disposal of property by or on behalf of the corporation, rents from municipal properties, fees of various kinds including fee on local licenses, and taxes including taxes on properties, Octroi (which has now been replaced by a Local Body Tax) and any other tax with prior approval from the state government. KDMC can also borrow funds from market after getting approval from the state government. Although the arrangements made under the BPMC Act, to an extent, fiscally empower the KDMC in delivering local services. Nonetheless, an analysis of the municipal body's finances is required in order to establish degree of fiscal autonomy of the KDMC.

Analysing KDMC's budgets, it becomes evident that KDMC registers an increase in income and expenditure of almost 5 times during 2005-2006 to 2011-2012 (refer to Table 1). While income rose up to Rs. 1135 Crores from roughly 228 Crores, expenditure went up from Rs. 222 Crores to Rs. 1261 Crores during the same period. Similarly, there has been an increase in per capita income of KDMC from Rs. 2035 in 2005-2006 to Rs. 9110 in 2011-2012 and its per capita expenditure from Rs. 1982 in 2005-2006 to Rs. 10121 in 2011-2012.

Such an increase in financial resources however, has been mainly due to a rising share of grants in the total income increasing from 6 percent in total income in 2005-2006 to 35 percent in total income in 2011-2012 (refer to Table 2). This increase has happened with a simultaneous decrease in the share of income from taxes in the total income of the corporation, while share of income from non-tax revenue (fees and user charges) has remained almost constant over the years, except for the year 2009-2010 and 2010-2011 (refer to Table 2). Further, analysing the expenditure side of the budgets, it comes out that the share of revenue expenditure in total expenditure has decreased from 82 percent in 2005-2006 to 54 percent in 2011-2012 together with an increase in the share of capital expenditure from 18 percent in 2005-2006 to 46 percent in 2011-2012 (refer to Table 3 below).

The analysis of income and expenditures of KDMC over past 7 years portrays an increase in financial resources with the corporation. The analysis, however, does not highlight the fiscal autonomy of the KDMC, both in terms of generating its income through own sources and spending the revenue generated on its own terms.

\begin{tabular}{|c|c|c|c|c|c|c|c|}
\hline Income and expenditure details of KDMC & 2005-2006 & 2006-2007 & 2007-2008 & 2008-2009 & 2009-2010 & 2010-2011 & 2011-2012 \\
\hline Total income (Rs. Crores) & 228.4 & 232.7 & 260.4 & 396.1 & 713.2 & 914.1 & 1135.1 \\
\hline Per capita income (Rs./capita) & 2035 & 2038 & 2241 & 3350 & 5928 & 7467 & 9110 \\
\hline Total exp. (Rs. Crores) & 222.5 & 260.2 & 272.7 & 307.3 & 747.0 & 897.1 & 1261.0 \\
\hline Per capita exp. (Rs./capita) & 1983 & 2278 & 2347 & 2599 & 6209 & 7328 & 10121 \\
\hline
\end{tabular}

Source: KDMC budgetary data (KDMC, n.d.); Census, 2001; Census, 2011; own analysis. 
Table 2. Share of income from tax, non-tax and grants in total income of KDMC.

\begin{tabular}{cccccccc}
\hline $\begin{array}{c}\text { Proportion of source of income in } \\
\text { KDMC's total income }\end{array}$ & $2005-2006$ & $2006-2007$ & $2007-2008$ & $2008-2009$ & $2009-2010$ & $2010-2011$ & $2011-2012$ \\
\hline Tax revenue/Total Income & $53 \%$ & $58 \%$ & $54 \%$ & $42 \%$ & $26 \%$ & $22 \%$ & $25 \%$ \\
Non Tax income/Total Income & $41 \%$ & $35 \%$ & $43 \%$ & $32 \%$ & $55 \%$ & $61 \%$ & $40 \%$ \\
Grants/Total Income & $6 \%$ & $7 \%$ & $3 \%$ & $26 \%$ & $19 \%$ & $17 \%$ & $35 \%$ \\
\hline
\end{tabular}

Source: KDMC Budgetary data (KDMC, n.d.) for the respective years; own interpretation.

Table 3. Share of revenue and capital expenditure in total expenditure of KDMC over the past 7 years.

\begin{tabular}{cccccccc}
\hline Share of total expenditure & $2005-2006$ & $2006-2007$ & $2007-2008$ & $2008-2009$ & $2009-2010$ & $2010-2011$ & $2011-2012$ \\
\hline Revenue expenses/Total expenses & $82 \%$ & $83 \%$ & $84 \%$ & $72 \%$ & $64 \%$ & $63 \%$ & $54 \%$ \\
Capital expenses/Total expenses & $18 \%$ & $17 \%$ & $16 \%$ & $28 \%$ & $36 \%$ & $37 \%$ & $46 \%$ \\
\hline
\end{tabular}

Source: KDMC Budgetary data (KDMC, n.d.) for the respective years; own interpretation.

The following analysis, therefore explores such aspects in detail.

An analysis of fiscal ratios, as identified by Chattopadhyay (2004), reveals that the percentage share of own source income of the Urban Local Body (ULB) in the total own income of the local, state and central government shows a steady progress after 2008-2009 with almost doubling of figures in the next two years (refer to Table 4 below). Reason behind such a drastic change in the trend could be the increasing efficiency in collection of taxes (in real terms) and increase in non-tax revenues (again in real terms), subsequent to the implementation of e-governance platform and JNNURM scheme. Similarly, share of revenue expenditure of ULB in total developmental expenditures of local, state and central government shows a steady progress after 2008-2009 values. Such increase after 2008-2009 can be attributable to both; increase in own source revenues at the local body’s end and increase in grants from the higher level governments for revenue works.

Interpretation of such an increase in fiscal ratios, however, must be done very carefully, as, increase in fiscal ratios do not necessarily indicate a higher level of fiscal autonomy of the KDMC. In fact, comparing this result with the analysis of the administrative measures of decentralisation reveal that, firstly, the revenue dependency of the KDMC-defined as the share of grants in total income over a period of past 7 years has increased from 6 percent in 2005-2006 to 35 percent in 2011-2012 (refer to Table 5). Secondly, investigating the source and purpose of grants from higher level governments (refer to Table 5) indicate a sharp decrease in the share of unconditional grants in total grants from around 30 percent in 2005-2006 to around 8 percent in 2011-2012. As majority of these grants are given through the JNNURM program, which intends urban reforms for the empowerment of the urban local bodies, it would be difficult to claim that there is a decrease in the discretion of the KDMC in putting these grants to use. Nonetheless, as state government, with its nodal agencies dealing with the JNNURM program, keeps an upper hand in the management and distribution of such grants within the whole state of Maharashtra, it could well be said that the KDMC's discretion in using higher level government grants has not increased with an increase in share of grants in total income.

The analysis of administrative measures, therefore, reveals that there has been a rise in dependency on higher level of governments for grants. Further, such a dependency has not been associated with an increase in KDMC's discretion in using such grants.

A similar analysis of the expenditure autonomy of the KDMC supports previous findings (refer to Table 6). Analysing the funding pattern of revenue expenditure from KDMC's own sources of income, it comes out that it has been increasingly getting difficult for the KDMC to fund revenue expenses from own sources of income with a rising share from 2005-2006 value of 84 percent to 2011-2012 figure of 109 percent. Further, analysing the share of ULB's discretionary expenditure in total local expenditure reveals a declining trend from 84 percent from 2005-2006 to 56 percent during 2010-2011.

The above analysis is quite revealing and showcases the true character of the fiscal autonomy of the KDMC. Although over the years, KDMC has become more fiscally decentralised with its relatively higher share in composite local, state and central revenues and expenditures, however, its revenue dependency on higher level government grants has increased. Further, such a dependency turns out to be of conditional nature with a decreasing trend in unconditional nature of grants. On the expenditure side, the analysis reveals a declining trend 
Table 4. Fiscal ratios for KDMC.

\begin{tabular}{cccccc}
\hline Fiscal measures & $2006-2007$ & $2007-2008$ & $2008-2009$ & $2009-2010$ & $2010-2011$ \\
\hline $\begin{array}{c}\text { Share of own income of the ULB in total own revenue of local, } \\
\text { state and central governments }\end{array}$ & $0.07 \%$ & $0.06 \%$ & $0.06 \%$ & $0.11 \%$ & $0.12 \%$ \\
$\begin{array}{c}\text { Share of revenue exp. of ULB in total developmental } \\
\text { expenditure of local, state and central governments }\end{array}$ & $0.10 \%$ & $0.09 \%$ & $0.06 \%$ & $0.10 \%$ & $0.11 \%$ \\
\hline
\end{tabular}

Source: KDMC budgetary data (KDMC, n.d.); (CAG, 2012); Public finance statistics of 2012, Ministry of Finance, Government of India (MoF, 2012).

Table 5. Revenue dependency and financial autonomy of the KDMC.

\begin{tabular}{cccccccc}
\hline Administrative measures & $\mathbf{2 0 0 5 - 2 0 0 6}$ & $\mathbf{2 0 0 6 - 2 0 0 7}$ & $\mathbf{2 0 0 7 - 2 0 0 8}$ & $\mathbf{2 0 0 8 - 2 0 0 9}$ & $\mathbf{2 0 0 9 - 2 0 1 0}$ & $\mathbf{2 0 1 0 - 2 0 1 1}$ & $\mathbf{2 0 1 1 - 2 0 1 2}$ \\
\hline Revenue dependency-Grants/Total Income & $6 \%$ & $7 \%$ & $3 \%$ & $26 \%$ & $19 \%$ & $17 \%$ & $35 \%$ \\
Financial autonomy-untied grants/Total grants & $30 \%$ & $21 \%$ & $34 \%$ & $10 \%$ & $4 \%$ & $11 \%$ & $8 \%$ \\
\hline
\end{tabular}

Source: KDMC budgetary data (KDMC, n.d.); own analysis.

Table 6. Expenditure autonomy of KDMC.

\begin{tabular}{|c|c|c|c|c|c|c|c|}
\hline Expenditure autonomy & 2005-2006 & 2006-2007 & 2007-2008 & 2008-2009 & 2009-2010 & 2010-2011 & 2011-2012 \\
\hline Revenue expenditure/Own source income & $84.6 \%$ & $100.3 \%$ & $90.2 \%$ & $84.3 \%$ & $91.6 \%$ & $88.4 \%$ & $108.8 \%$ \\
\hline$\%$ of local expenditure under own discretion & $83.6 \%$ & $84.7 \%$ & $84.6 \%$ & $74.7 \%$ & $64.5 \%$ & $64.9 \%$ & $56.1 \%$ \\
\hline
\end{tabular}

Source: KDMC budgetary data (KDMC, n.d.); own analysis.

in expenditure autonomy of KDMC both due to an increasing share of revenue expenditure funded by own source revenue and a declining trend in KDMC's discretionary expenditure in the total local expenditure by the KDMC. In summary, a budgetary analysis of past 7 years showcases a declining trend in fiscal autonomy of the KDMC.

\subsection{Direction of Accountability in KD}

In order to analyse the direction of accountability in $\mathrm{KD}$, it requires assessing effectiveness of information sharing mechanisms between KDMC and higher level governments (i.e., upward accountability) and also between KDMC and local citizenry (i.e., downward accountability). While the JNNURM program has been very successful in strengthening upward accountability of the KDMC mainly through its sharing of monthly and quarterly progress reports of projects undertaken under the City Development Plan (CDP), prepared as a mandatory requirement for the release of grants and loans from higher level governments. The tech-enabled e-grievance redressal, a part of e-governance mechanism, has played an insignificant role in making the local government more responsive and capturing the requirements of those in the most need (Martinez, Pfeffer, \& Dijk, n.d.). A further account of effectiveness of various points of interfaces between KDMC and local citizenry is presented in the following section.

There are broadly four kinds of urban formations within KD-authorised settlements, unauthorised settlements; urban villages and slums (van Dijk \& Sridharan, 2009). Authorised settlements are inhibited by a small percentage of KD's population. The built form within this category comprises apartments, villas, and private townships. Unauthorised settlements, on the other hand, are inhibited by a majority of KD's population. Recent estimate bring out that more than 70 percent of the buildings within KD are unauthorised (CDP, 2007). Urban villages, which were once rural settlements, are now surrounded by the city. Most of the tenements within these villages are built on agricultural land. And lastly, there are slums, which are marked by self-help substandard housing, and poor basic amenities. Slums comprise 40 - 44 percent of KD's population.

In order to assess effectiveness of points of interfaces between local citizens and the local government in bringing transparency and accountability in local governance, a pilot survey was conducted in 2012 (refer Table 17, pg. 50 within Baud et al., 2013) which was again repeated in 2013, with a focus on slum households. These surveys reveal that most of the residents of the authorised settlements have not met the local government during the last one year for reasons other than local taxes and are quite satisfied with the system. However those who have met rely either on local councillors or prefer contacting the local government, directly. Respondents also 
highlight that their problems were resolved during such interactions.

The residents of unauthorised settlements reveal that they have met the local government during last one year for purpose other than taxes. Approximately half of the respondents under this category have relied upon their linkages with the KDMC officials, local councillors and rest half of the respondents went up to the office of the local government for their issues. However, only few of them reveal satisfactory outcomes of such representations. Interviewing residents of urban villages, it comes out that most of them have contacted local government once during last one year by reaching out to their contacts within the local government and by claiming their memberships of some political group. Residents of these groups reveal that their concerns were promptly resolved.

Lastly, interviewing slum dwellers, it comes out that a substantial number of them have raised their concern related to basic services with the local councillors and party workers within their slums and very few of them have approached the KDMC directly (either individually or in groups). Nevertheless, those who have approached the local government directly, revealed higher satisfaction levels compared to those who used other means.

Household surveys therefore highlight that citizens in KD use an array of mechanisms in expressing their agency to the local state depending upon the type of urban formation they belong to and upon the status of their entitlements provided by the local government through various programs (van Dijk \& Sridharan, 2009). Many of these mechanisms however do not increase transparency and accountability in local governance. For instance, mediations of local councillors, political party workers, middlemen, and memberships of political groups strengthen "political patronage" in local democracy. By benefiting particular identities (elites, interest group, co-ethnics), politicians ensure continued support and opportunities for realising rents for themselves (Harriss, 2010).

Further, there is also a near absence of civil society organisations in KD. To the extent there are a few non-government organisations (NGOs)/community based organisations (CBOs) that operate in KD (of which 8 were interviewed during field visit to KD in April 2013; refer to Table 7); it was observed that these organisations find it increasingly difficult to push their objectives with the local government. These civic bodies also face issues of resource constraints which affect their proper functioning.

\section{Discussion}

The case analysis reveals the current state of decentralisation in Kalyan-Dombivli in terms of its local body's scope of authority, degree of autonomy and direction of accountability in the period of ongoing urban reforms. While the authority of the KDMC has been constrained mainly due to an increasing role played by state government's technical bodies in local development, its autonomy, both in terms of generating its income through own sources and spending the revenue generated on its own terms, decreased with the increasing role of Central government grants in local revenues and expenditure. Further, even relying on technology for increasing the access of local citizens to the local government has not helped KDMC in becoming more responsive. In absence of any established (downward) accountability mechanism in KD (including the civil society), most of the existing mechanisms of expressing agency to the local government strengthen "political patronage".

In sum, the idea behind creating "institutions of local self governance" by amending the Constitution of India has not gained its currency in KD. Higher level governments increasingly affect the process of empowerment of the local body, be it through its technocratic bodies (parastatals) or through various urban regeneration programs. One such program is JNNURM which has not only affected the fiscal autonomy of the local body in KD, but has also transformed the local governance through co-optation and invitation (at the time of project identification and CDP preparation) thereby impacting the regulatory environment and the nature of interventions. To the extent there is an increase in fund flow for local development with the KDMC through JNNURM funding, an absence of accountability mechanisms operating at the local level, increases the possibilities of involvement of distributive politics - pork barrel, favouritism, etc., planning and in allocation of such funds.

The case analysis of KD, therefore, highlights a continuous effort of the higher level governments in re-centralisation of decision making from local government towards higher level bodies. Sustainability of urban development in KD is, therefore at stake. Further, being a fringe city to Mumbai, Kalyan-Dombivali also risks from a gradual shift in demographic structure resulting from gentrification and peripheralisation of poor from 
Table 7. Summary of Interviews with the local NGOs/CBOs.

\begin{tabular}{|c|c|c|c|c|c|}
\hline Name of NGOs & Nature of work & $\begin{array}{l}\text { Localities } \\
\text { covered }\end{array}$ & Composition & $\begin{array}{l}\text { No. of times got success in } \\
\text { propagating their agenda } \\
\text { through the local } \\
\text { government }\end{array}$ & $\begin{array}{l}\text { If resource constraint is one } \\
\text { of the reasons in their } \\
\text { non-effectiveness }\end{array}$ \\
\hline Sarvatmaka & $\begin{array}{l}\text { Women health, HIV } \\
\text { AIDS, Child labour } \\
\text { School, Counselling } \\
\text { centres }\end{array}$ & $\begin{array}{l}\text { Kalyan, Dombivli, } \\
\text { Ulhasnagar }\end{array}$ & $\begin{array}{l}5+\text { volunteers; } \\
\text { each time they } \\
\text { go out in } \\
\text { community }\end{array}$ & $\begin{array}{l}\text { They work in partnership with } \\
\text { the local govt. therefore no } \\
\text { scope of objecting on } \\
\text { government's actions }\end{array}$ & $\begin{array}{l}\text { Yes, financial resources were a } \\
\text { big issue and because of this, } \\
\text { they had to quit from many } \\
\text { activities }\end{array}$ \\
\hline $\begin{array}{c}\text { Prem Seva } \\
\text { Mahila Mandal }\end{array}$ & $\begin{array}{l}\text { Educating } \\
\text { underprivileged } \\
\text { children and women } \\
\text { welfare, migrants } \\
\text { and tribals }\end{array}$ & $\begin{array}{l}\text { Bhiwandi, Vasai } \\
\text { Road, Kalyan, } \\
\text { Dombivli }\end{array}$ & $\begin{array}{c}15+40 \\
\text { volunteers }\end{array}$ & $\begin{array}{c}\text { Once, over mid-day meal } \\
\text { preparation }\end{array}$ & $\begin{array}{l}\text { yes, if they have more } \\
\text { resources, they can definitely } \\
\text { address many issues on their } \\
\text { own, without approaching } \\
\text { local government }\end{array}$ \\
\hline $\begin{array}{l}\text { Rotary Club } \\
\text { Kalyan, Rotary } \\
\text { club Dombivli }\end{array}$ & $\begin{array}{l}\text { Education, Health } \\
\text { etc. (Charity) }\end{array}$ & $\begin{array}{l}\text { both Kalyan and } \\
\text { Dombivli }\end{array}$ & 66 & $\begin{array}{l}\text { once, for availing land in } \\
\text { order to provide public toilet } \\
\text { and drinking water fountains } \\
\text { near railway station }\end{array}$ & No \\
\hline $\begin{array}{c}\text { Manav Sahayak } \\
\text { Sewa Mandal }\end{array}$ & $\begin{array}{l}\text { Educating slum } \\
\text { dwellers, career } \\
\text { counselling, health } \\
\text { campaign }\end{array}$ & KDMC area & 50 & $\begin{array}{l}\text { Many times; operating since } \\
1982\end{array}$ & $\begin{array}{l}\text { Yes, human resource, people } \\
\text { have gradually left and } \\
\text { functioning of the organisation } \\
\text { has become weaker }\end{array}$ \\
\hline $\begin{array}{l}\text { Association of } \\
\text { Christian's } \\
\text { social welfare }\end{array}$ & $\begin{array}{l}\text { Charity, communal } \\
\text { interests, education } \\
\text { and health }\end{array}$ & Kalyan & 30 & $\begin{array}{l}\text { Several times, but mainly } \\
\text { through demonstrations. }\end{array}$ & No \\
\hline $\begin{array}{c}\text { Parivartan } \\
\text { Mahila sanstha }\end{array}$ & $\begin{array}{l}\text { Women; } \\
\text { empowerment, skill } \\
\text { development, } \\
\text { counselling, } \\
\text { healthcare, and } \\
\text { shelter }\end{array}$ & Thane district & $9+$ volunteers & $\begin{array}{l}\text { Several times; mainly over } \\
\text { women self help groups and } \\
\text { vocational activities }\end{array}$ & Yes \\
\hline $\begin{array}{l}\text { Kadambari } \\
\text { Foundation }\end{array}$ & local environment & KDMC area & 45 & $\begin{array}{l}\text { Work in collaboration with } \\
\text { the KDMC and state } \\
\text { government }\end{array}$ & Yes, human resource \\
\hline $\begin{array}{l}\text { Dattanagar } \\
\text { Janahit Sangh }\end{array}$ & $\begin{array}{l}\text { To save the local } \\
\text { residents from local } \\
\text { politicians' extortion } \\
\text { on matters related to } \\
\text { their relocation } \\
\text { during } \\
\text { redevelopment of } \\
\text { their slum }\end{array}$ & $\begin{array}{l}\text { Datta Nagar, } \\
\text { Dombivli }\end{array}$ & 374 households & Never & No, local residents contribute \\
\hline
\end{tabular}

Source: NGO survey conducted in April 2013.

Mumbai and other nearby areas (see for instance Patkar \& Singh, 2007; Banerjee-Guha, 2009). This can manifest in the proliferation of informal settlements and slums in KD, making it a vicious cycle which would be difficult to break through local interventions. JNNURM program has already re-centred KDMC's scope in local interventions.

For the local development to be inclusive and sustainable in KD, it is therefore important that KDMC resumes its (fiscal) autonomy and (functional) authority in both generating its income through own sources and spending the revenue generated on its own terms over local development plans and policies. This would essentially require devolving more powers from the state government and an active collaboration between state's technomanagerial bodies and the local body in physical and socio-economic planning and also in program implementation. Moreover such plans and programs must include local public priorities, including that of the poor. This necessitates a rights based approach in strengthening the status of citizens from that of beneficiaries of development to its rightful and legitimate claimants. 


\section{Acknowledgements}

The author acknowledges the generous financial support and an excellent platform for sharing research findings provided by the Chance2sustain (www.chance2sustain.eu) project of the European Union. The views and opinion presented in this paper, however, are those of the author's and not of the funding agency.

\section{References}

Baid, K. (2008). Spatial Structure of a City, Case Study, Kalyan Dombivili. Mumbai, SPA, UP 857.

Bagchi, S. (2003). Decentralised Urban Governance in India: Implications for Financing of Urban Infrastructure. 1-28. http://www.mumbaidp24seven.in/reference/31SoumenBagchi.pdf

Banerjee-Guha, S. (2009). Neoliberalising the "Urban”: New Geographies of Power and Injustice in Indian Cities. Economic and Political Weekly, 44, 95-107.

Batra, L. (2009). A Review of Urbanisation and Urban Policy in Post-Independent India. Working Paper Series, New Delhi: Jawaharlal Nehru University.

Baud, I. et al. (2013). The Development of Kalyan Dombivili; Fringe City in a Metropolitan Region (City Report No. 2), City Growth and the Sustainability Challenge Comparing Fast Growing Cities in Growing Economies. Bonn: Chance 2 Sustain Project.

Bird, R., \& Wallich, C. (1993). Fiscal Decentralization and Intergovernmental Relations in Transition Economics: Toward a Systematic Framework of Analysis. World Bank Policy Research Working Papers, Public Economics 1-92.

Bhatnagar, S. (2007). Information Technology in Developing Countries. Ahmedabad: Citizen Facilitation Centres (CFC) of KDMC. http://www.iimahd.ernet.in/egov/ifip/aug2007/aug2007.pdf

CAG, I. (2012). Audit Report (State Finances) for the Year Ended 31st March 2011 (Maharashtra State Financial Audit Report). New Delhi: Comptroller and Auditor General of India.

CDP (2007). City Development Plan for Kalyan Dombivli Municipal Corporation (Tech Report No. 1). Kalyan Dombivli: JNNURM.

CDP (2012). City Development Plan for Kalyan Dombivali Municipal Corproration (Tech Report No. 2). Kalyan Dombivli: JNNURM.

Census, (2001). Census of India 2001 (Provisional) Slum Population in Million Plus Cities (Municipal Corporations): Part A. Census of India [WWW Document]. http://censusindia.gov.in/Tables_Published/Admin_Units/Admin_links/slum1_m_plus.html

Census (2011). Kalyan and Dombivali City Census 2011 Data [WWW Document]. http://www.census2011.co.in/census/city/369-kalyan-and-dombivali.html

Chattopadhyay, S. (2004). Strengthening Local Governments: Urban Fiscal Decentralization in India. International Journal of Regulation and Governance, 4, 75-112.

Coelho, K., Kamath, L., Vijaybaskar, M. (2011). Infrastructures of Consent: Interrogating Citizen Participation Mandates in Indian Urban Governance. IDS Working Paper 362.

Denis, E., Mukhopadhyay, P., Zérah, M.-H. (2012). Subaltern Urbanisation in India. Economic and Political Weekly, Review of Urban Affairs, xlviI, 52-62.

Duc, V. (2008). The Economics of Measuring Fiscal Decentralisation Part 1: An Overview of Recent Insights into Fiscal Decentralisation. Economics Discussion/Working Papers No. 08-13, Crawley: The University of Western Australia.

MMRDA Website (2013). Mumbai Metropolitan Regional Development Authority. MMRDA [WWW Document]. http://mmrda.maharashtra.gov.in/

MoF (2012). Indian Public Finance Statistics. New Delhi: Ministry of Finance, Government of India.

Nishandar, V. (2011). A Study of Citizen Facilitation Centre of Kalyan Dombivali Municipal Corporation, Maharshtra. International Referred Research Journal, III, 56-58.

Halder, P, (2007). Measures of Fiscal Decentralization. Andrew Young School of Policy Studies Summer Internship Program, Atlanta: Georgia State University.

Harriss, J. (2010). Is Government in India Becoming More Responsive? Has Democratic Decentralisation Made a Difference? Working Paper No. 08/2010, Simons Papers in Security and Development, Vancouver: School for International Studies, Simon Fraser University.

IDF (n.d.). Urban Local Bodies: Decentralisation and Sustainance, Assessment of Decentralisation Process in India. Reserach Report, IDF, 1-36.

KDMC (n.d). KDMC Budgetary Data for Respective Years (Budgetary Data Series). Kalyan Dombivli: Kalyan Dombivli 
Municipal Corporation.

Martinez-Vazquez, J., \& Timofeev, A. (2009). Decentralisation Measure Revisited. Atlanta, GA: Andrew Young School of Policy Studies, International Studies Program 09-13.

Martinez, J., Pfeffer, K., \& van Dijk, T. (n.d.). The Capacity of e-Government Tools: Claimed Potentials/Unnamed Limitations. http://www.n-aerus.net/web/sat/workshops/2009/Rotterdam/pdf/Martinez_Pfeffer_van\%20Dioj.pdf

Mukhopadhyay, P. (2006). Whither Urban Renewal? Economic and Political Weekly, 41, 879-884.

Patkar, M., \& Singh, S. (2007). Urban Renewal: At Whose Cost? Economic and Political Weekly, 42, 926-928.

Pethe, A., Gandhi, S., \& Tandel, V. (2011). Assessing the Mumbai Metropolitan Region: A Governance Perspective. Economic and Political Weekly, Special Article, 46, 187-195.

Rao, M. G., \& Bird, R. (2010). Urban Governance and Finance in India. New Delhi: NIPFP Working Paper No. $2010-68$.

van Dijk, T. K., \& Sridharan, N. (2009). Profile of an Urbanized Society? Slums, Gauthans, and Lifestyle City in Kalyan-Dombivli, India. International Forum on Urbanism Conference, University of Delft, Delft, 27-28 November 2009,

Woolman, H., \& Goldsmith, M. J. (1990). Local Autonomy as a Meaningful Concept. Comparing Local Government in the United States and in the United Kingdom. Urban Affairs Review, 26, 3-27.

http://dx.doi.org/10.1177/004208169002600101 
Scientific Research Publishing (SCIRP) is one of the largest Open Access journal publishers. It is currently publishing more than 200 open access, online, peer-reviewed journals covering a wide range of academic disciplines. SCIRP serves the worldwide academic communities and contributes to the progress and application of science with its publication.

Other selected journals from SCIRP are listed as below. Submit your manuscript to us via either submit@scirp.org or Online Submission Portal.
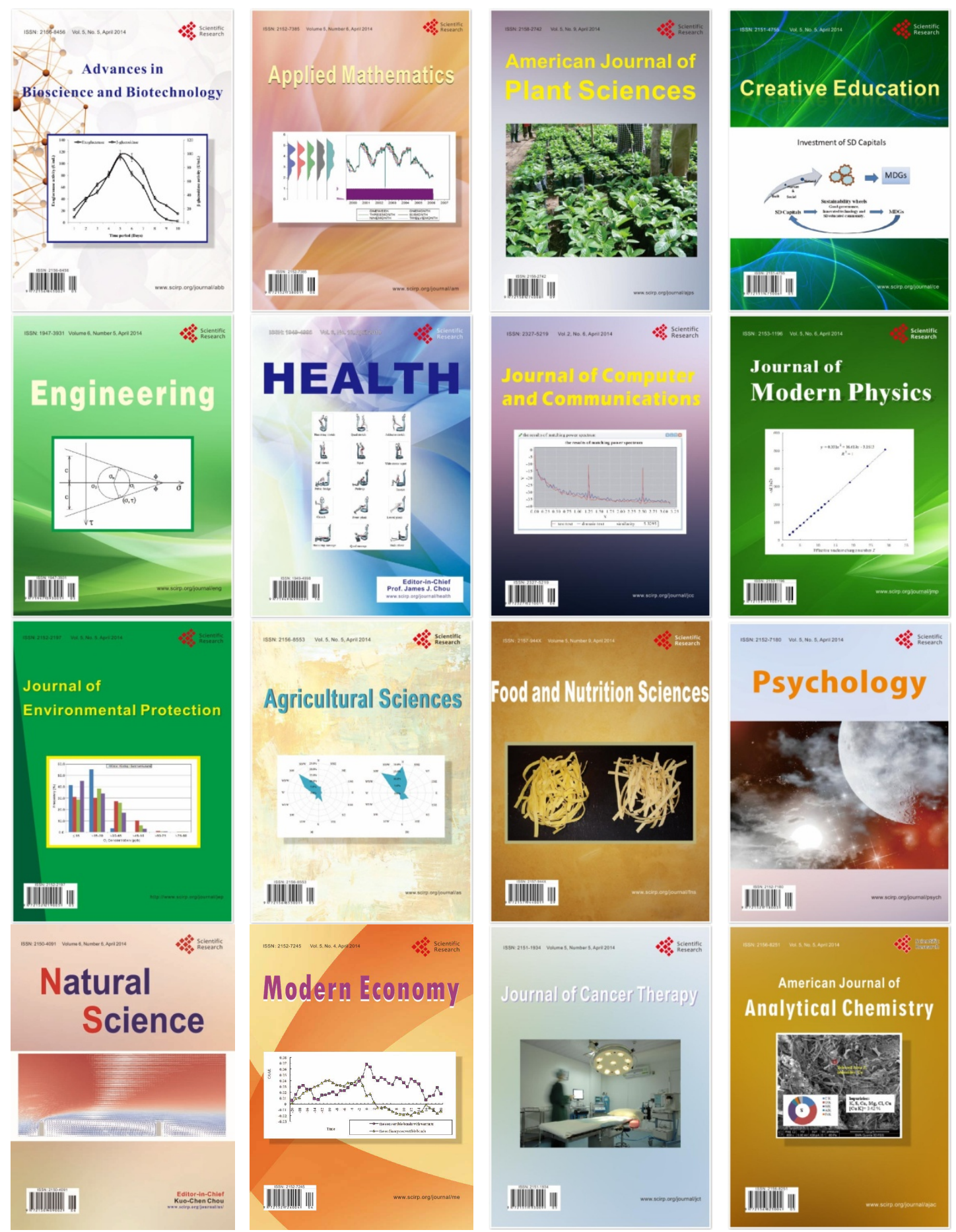